\title{
Evaluation of Attitudes and Knowledge Levels of University Employess towards Rational Drug Use and Health Perception
}

\author{
Üniversite Çalışanlarının Akılcı İlaç Kullanımı ve Sağlık Algısına Yönelik Tutum ve Bilgi Düzeylerinin \\ Değerlendirilmesi
}

\author{
Sema ÇíFÇi' ${ }^{1}$, Vasfiye BAYRAM DEĞER ${ }^{2}$, Nilgün ULUTAŞDEMIR ${ }^{3}$
}

\begin{abstract}
This survey study was aimed at determining the Rational Drug Use (RDU) behaviors and health perceptions of the staff working in a state university.

The population of this cross-sectional study consists of all the staff working in a state university in Turkey. The study sample consisted of a total of 342 staff including academicians, administrative personnel, janitors and security guards. The data were collected through an online questionnaire due to pandemic precautions. The obtained data were recorded on the SPSS version 18 program and descriptive statistics, normality tests, Mann-Whitney U test, Kruskal-Wallis test, and Spearman correlation were used in the analysis.

The mean age of the participants in the study were found to be $36,54 \pm 8,05$. $79,2 \%$ of the participants were male. $29,2 \%$ of them had a $\mathrm{PhD} .44,4 \%$ were academic staff working in all departments while $55,6 \%$ included administrative personnel, janitors and security guards. The RDU knowledge mean scores of the participants $(35,69 \pm 5,30)$ were considered sufficient. It was found that factors such as personal and parental educational status, profession, socioeconomic level, family type, gender, and distance from the health center of the residence had important effects on Rational Drug Use $(p<0,05)$. The participants' health perceptions were at moderate level $(51,15 \pm 7,97)$. It was revealed that educational status, profession, and socioeconomic level affected the perception of health $(\mathrm{p}<0,05)$. To improve rational drug use and health perceptions, it is crucial to reveal the current situation, and to determine the level of knowledge and attitudes of individuals. Training, studies, and social policies aimed at promoting the perception of health and rational drug use should be made widespread.
\end{abstract}

Keywords: Rational drug use, University staff, Perception of health, Attitude

\section{ÖZ}

$\mathrm{Bu}$ araştırma bir devletcen üniversitesinde görev yapan personellerin Akılcı İlaç Kullanımı (AİK) davranışlarının ve sağlık algılarının belirlenmesi amacı ile yapılmıştır.

Kesitsel tipteki bu araştırmanın evrenini Türkiye'de bir devlet üniversitesinde görev yapan tüm personel oluşturmuştur. Araştırma, çalışmaya katılmayı kabul eden 342 personelle tamamlanmıştır. Araştırmanın verileri, pandemi koşullarından dolayı, çevrimiçi anket aracılığıyla toplanmıştır. Elde edilen veriler, SPSS 18 programına kaydedilerek, analizlerde tanımlayıcı istatistikler, normallik testleri, MannWhitney U testi, Kruskal-Wallis testi ve Spearman korelasyon kullanılmıştır.

Araştırmaya katılan bireylerin yaş ortalaması $36,54 \pm 8,05$ olarak bulunmuştur. Bireylerin \%79,2'si erkek, \%29,2'si doktora mezunu, \%44,7'si akademik personeldir. Bireylerin AİK bilgi puan ortalamas1 $(35,69 \pm 5,30)$ yeterli düzeyde olup, Akılcı İlaç Kullanımını, eğitim durumu, anne ve baba eğitim durumu, meslek, ekonomik düzey, aile tipi, cinsiyet ve yaşadığı yerin sağlık merkezine uzaklığı gibi faktörler etkilemektedir $(p<0,05)$. Bireylerin sağlık algısı ise orta derecede $(51,15 \pm 7,97)$ olup sağlık algısını eğitim, meslek ve sosyoekonomik düzey etkilemektedir $(\mathrm{p}<0,05)$. Akılcı ilaç kullanımı ve sağlı algısı konularında önemli adımlar atılabilmesi için öncelikle bu konulardaki mevcut durumun ortaya konmas1, bireylerin bu konulardaki bilgi düzeyleri ve tutumlarının belirlenmesi gerekmektedir. Sağlık algısı ve İlaç kullanımı bilincinin arttırılmasına yönelik eğitimler, araştırmalar ve sosyal politikalar yaygınlaştırılmalıdır.

Anahtar Kelimeler: Akılcı ilaç kullanımı, Üniveriste personeli, Sağlık algısı, Tutum

\footnotetext{
Ethical permission was obtained from the ethics committee of Mardin Artuklu University for this research (Date: 08.11.2019 and numbered 2019/01-3)

1 Dr. Öğr. Üyesi, Halk Sağlığı, Sema ÇİFÇİ, Mardin Artuklu Üniversitesi Sağlık Bilimleri Fakültesi Hemşirelik Bölümü, sema$2121 @$ hotmail.com, ORCID: 0000-0003-3297-2931

${ }^{2}$ Doç. Dr., Halk Sağlığı, Vasfiye BAYRAM DEĞER, Mardin Artuklu Üniversitesi Sağlık Bilimleri Fakültesi Hemşirelik Bölümü, vasfiyedeg@gmail.com, ORCID: 0000-0002-7714-9087

3 Doç. Dr., Halk Sağlığı, Nilgün ULUTAŞDEMİR, Gümüşhane Üniversitesi Sağlık Bilimleri Fakültesi Sağlık Yönetimi Bölümü, nulutasdemir@yahoo.com, ORCID: 0000-0002-2231-5236
}

İletişim / Corresponding Author: Vasfiye BAYRAM DEĞER

Geliș Tarihi / Received: 29.05.202

e-posta/e-mail:

vasfiyedeg@gmail.com

Kabul Tarihi/Accepted: 17.12 .2021 


\section{INTRODUCTION}

A drug is a product or a substance that is used or anticipated to be used to alter physiological systems or pathological conditions for the benefit of the patient. ${ }^{1}$ As defined by Paracelsus, a Swiss scientist, who is considered to be the founder of toxicology, "every substance includes some poison and there is no substance without poison. It is the dosage that separates the poison from the drug" underlines that the drug used to treat the patient may cause different health problems in case of improper use ${ }^{2}$. Rational Drug Use (RDU) was defined as "people's capability to easily access to appropriate medication at the appropriate time and dose at the lowest cost given their clinical findings and individual characteristics" by the World Health Organization (WHO). The meeting held by WHO in Nairobi in 1985 is regarded as the onset of Rational Drug Use (RDU) studies. ${ }^{3}$ WHO estimates that more than half of all drugs are improperly prescribed, dispensed, or sold, and half of all patients do not take them correctly. Excessive, inadequate, or misuse of drugs causes wasting of scarce resources and common health hazards. ${ }^{4}$ The purpose of RDU is to reduce the social and financial burden arising from the misuse of drugs in general and to prevent negative conditions in physiological, biological, and psychological domains. It is known that individuals' perception of their health positively affects their behaviors related to maintaining health. ${ }^{5}$

Behaviors and applications not suitable for RDU include prescribing more drugs than needed, using drugs incorrectly, taking expensive drugs unnecessarily, using drugs without consulting the physician, discontinuing the drugs used before the prescribed period, altering the dose of drugs without consulting the physician, and not using the drugs on time. ${ }^{6-8}$ There are many underlying reasons for the inappropriate use of drugs, including false beliefs of individuals, healthcare professionals' lack of knowledge about drugs, poor communication between healthcare professionals and patients, errors and insufficiencies in health education, excessive and irrational prescriptions, the overwhelming burden of patient care, insufficient diagnostic facilities, the uncertainty of diagnosis, patient demands, problems in drug distribution, promotional activities of pharmaceutical companies, drug prescribing requests of patients, defective drug supply systems, legal regulations regarding drugs, etc. 9,10

Perception of health can be defined as a combination of an individual's personal feelings, thoughts, prejudices, and expectations about his health. ${ }^{11}$ One's perception of health is closely associated with learning and maintaining healthy lifestyle behaviors and improving health. ${ }^{12,13}$ How an individual perceives healthy behaviors is effective in exhibiting other health-related behaviors. If the individual cannot perceive their health problems, they will not make the necessary effort to improve their health, thus not seeking help from professionals. It is vital to know about how individuals perceive health risks, how accurate these perceptions are, and how they get information about their health risks. ${ }^{12}$ Nurses have important duties and responsibilities in this process. They should evaluate the patient's perception of health and health behaviors and guide his development. ${ }^{13,14}$ The RDU and health perceptions of university staff, especially health professionals, who have a leading role in building consciousness in the society, can provide an invaluable insight into the awareness levels of other segments of the society about this issue.

This survey study was aimed at determining the Rational Drug Use behaviors and health perceptions of the staff working in a state university. 


\section{MATERIAL AND METHODS}

The population of this cross-sectional study consists of the entire staff working at a state university located in upstate in Turkey. The study sample included 342 staff who agreed to participate. The data were collected between 01.04.2020-01.05.2020 through an online survey due to pandemic precautions. The questionnaire prepared by the researchers in the light of the literature consists of 3 sections. The first section was designed as a personal information form to determine the socio-demographic characteristics of the staff. The second section included the "Rational Drug Use Scale" to evaluate the level of knowledge. The third section included the "Health Perception Scale" to determine the level of attitudes. The Rational Drug Use Scale developed by Demirtaş et al. (2018), which was proved to be valid and reliable, evaluates the Rational Drug Use knowledge of adults. The scale used to determine the level of Rational Drug Use knowledge is the first of its kind with a valid and reliable structure made in Turkey. There are 21 questions on the scale, and in line with the answers given, it is scored in the following: Yes: 2 points, I don't know: 1 point, No: 0 points. Items 2, 5, $6,9,10,13,15,16,17,19,20$ are reversely proposed and scored. The higher scores obtained from the scale indicate that the knowledge level of Rational Drug Use is high. The cut-off value for the scale was calculated as 34 points, and individuals who score 35 points and above will be evaluated as "having a basic knowledge level of Rational Drug Use ". ${ }^{15}$ The Turkish adaptation of the Health Perception Scale (HPS) developed by Diamond et al., along with the validity and reliability studies, was carried out by Kadıoglu and Y1ldız. HPS is a five-point Likert-type scale consisting of 15 items and four sub-factors. Items 1, 5, 9, 10, 11 , and 14 refer to positive attitudes while items $2,3,4,6,7,8,12,13$, and 15 refer to negative statements. Positive statements are scored in the following: "I strongly agree $=5$ points", "I agree $=4$ points ", "Undecided $=3$ points ", "Disagree = 2 points ", "I do not agree at all $=1$ point". Negative statements are scored reversely. The minimum score that can be obtained from the scale is 15 points while the highest score is 75 points. ${ }^{16}$

The collected data were recorded on the SPSS 18 statistical package program and descriptive statistics (including means and percentages), normality tests, Mann-Whitney U Test, Kruskal-Wallis Test, and Spearman correlation were used in the analysis of the data. The Mann-Whitney $U$ test with Bonferroni correction was used as a post-hoc procedure to determine the source of the difference as a result of the Kruskal-Wallis Test. Cronbach alpha coefficient was used in the internal consistency analysis of the scales. $\mathrm{p}<0.05$ was considered significant.

\section{Ethical Aspect of Research}

The patients were informed about the study and their consent was obtained. In order to conduct the study and collect the data, institutional permission was obtained from Mardin Artuklu University ethic committee (Date: 08.11.2019 and numbered 2019/01-3). This study was conducted in accordance with the ethical principles stated in the Declaration of Helsinki.

\section{RESULTS AND DISCUSSION}

The mean age of the participants in the study was 36,54 $\pm 8,05$ (Min: 19, Max: 64). $44,4 \%$ of the individuals participating in the research are academic staff (including all branches), 33,4\% are administrative staff, $7,9 \%$ are security staff and $14,3 \%$ are cleaning staff. $79,2 \%$ of the participants were male. $34,8 \%$ of them were smokers. $11,7 \%$ of them had a chronic disease. The sociodemographic characteristics of the participants are presented in Table 1. 
GÜSBD 2021; 10(4): 943 - 954

Gümüşhane Üniversitesi Sağlık Bilimleri Dergisi

Gümüşhane University Journal of Health Sciences

Araștırma Makalesi

GUJHS 2021; 10(4): 943 - 954

Table 1. Sociodemographic Characteristics of the Participants

\begin{tabular}{|c|c|c|c|}
\hline Sociodemographic Characteristics ( $N=\mathbf{3 4 2}$ ) & & $\mathbf{N}$ & $\%$ \\
\hline \multirow[t]{4}{*}{ Age } & 18-25 Years & 24 & 7,0 \\
\hline & 26-35 Years & 147 & 43,0 \\
\hline & 36-45 Years & 124 & 36,3 \\
\hline & 45 Years and above & 47 & 13,7 \\
\hline \multirow[t]{2}{*}{ Gender } & Male & 271 & 79,2 \\
\hline & Female & 71 & 20,8 \\
\hline \multirow[t]{2}{*}{ Marital status } & Single & 93 & 27,2 \\
\hline & Married & 249 & 72,8 \\
\hline \multirow[t]{6}{*}{ Personal Educational status } & Literate & 4 & 1,2 \\
\hline & Primary School & 26 & 7,6 \\
\hline & High School & 61 & 17,8 \\
\hline & Undergraduate & 109 & 31,9 \\
\hline & Graduate & 42 & 12,3 \\
\hline & Doctorate & 100 & 29,2 \\
\hline \multirow[t]{5}{*}{ Maternal Educational Status } & Illiterate & 153 & 44,7 \\
\hline & Literate & 64 & 18,7 \\
\hline & Primary School & 84 & 24,6 \\
\hline & High School & 31 & 9,1 \\
\hline & Undergraduate & 10 & 2,9 \\
\hline \multirow[t]{5}{*}{ Paternal Educational Status } & Illiterate & 50 & 14,6 \\
\hline & Literate & 64 & 18,7 \\
\hline & Primary School & 117 & 34,2 \\
\hline & High School & 78 & 22,8 \\
\hline & Undergraduate & 33 & 9,6 \\
\hline \multirow[t]{4}{*}{ Profession } & Academic Staff & 152 & 44,4 \\
\hline & Administrative Staff & 114 & 33,4 \\
\hline & Security guard & 27 & 7,9 \\
\hline & Cleaning & 49 & 14,3 \\
\hline \multirow[t]{5}{*}{ Financial Status } & Very low & 17 & 5,0 \\
\hline & Poor & 29 & 8,5 \\
\hline & Moderate & 172 & 5,3 \\
\hline & Satisfactory & 110 & 32,2 \\
\hline & High & 14 & 4,1 \\
\hline \multirow{3}{*}{ Residence } & Province & 277 & 81,0 \\
\hline & District & 59 & 17,3 \\
\hline & Village & 6 & 1,8 \\
\hline \multirow[t]{2}{*}{ Smoking } & Yes & 119 & 34,8 \\
\hline & No & 223 & 65,2 \\
\hline \multirow[t]{2}{*}{ Drinking Alcohol } & Yes & 20 & 5,8 \\
\hline & No & 322 & 94,2 \\
\hline \multirow[t]{2}{*}{ Having a chronic illness } & Yes & 40 & 11,7 \\
\hline & No & 302 & 88,3 \\
\hline \multirow[t]{2}{*}{ Hypertension } & Yes & 5 & 1,5 \\
\hline & No & 337 & 98,5 \\
\hline \multirow[t]{2}{*}{ Cardiac disease } & Yes & 7 & 2,0 \\
\hline & No & 335 & 98,0 \\
\hline \multirow[t]{2}{*}{ Diabetes } & Yes & 4 & 1,2 \\
\hline & No & 338 & 98,8 \\
\hline \multirow[t]{2}{*}{ Asthma } & Yes & 10 & 2,9 \\
\hline & No & 332 & 97,1 \\
\hline \multirow[t]{2}{*}{ Renal Failure } & Yes & 2 & 0,6 \\
\hline & No & 340 & 99,4 \\
\hline Continuous drug use & Yes & 39 & 11,4 \\
\hline & No & 303 & 88,6 \\
\hline Domestic drug use & Yes & 136 & 39,8 \\
\hline & No & 206 & 60,2 \\
\hline Presence of Disabled individual at home & Yes & 25 & 7,3 \\
\hline & No & 317 & 92,7 \\
\hline Distance to the health facility from residence & Less than $1 \mathrm{~km}$ & 164 & 48,0 \\
\hline & More than $1 \mathrm{~km}$ & 178 & 52,0 \\
\hline
\end{tabular}


The distribution of the participant's answers given to the questions in the RDU scale of the participants is shown in Table 2.

Table 2. The Distribution of the Answers Given to the Questions in the RDU Scale

\begin{tabular}{|c|c|c|c|c|c|c|}
\hline \multirow[t]{2}{*}{ Statements $(\mathrm{N}=342)$} & \multicolumn{2}{|c|}{ Yes } & \multicolumn{2}{|c|}{ No } & \multicolumn{2}{|c|}{ I don't know } \\
\hline & $\mathbf{N}$ & $\%$ & $\mathbf{N}$ & $\%$ & $\mathbf{N}$ & $\%$ \\
\hline 1. Only physicians can suggest medication. & 306 & 89,5 & 30 & 8,8 & 6 & 1,8 \\
\hline $\begin{array}{l}\text { 2. It does not matter recommending medication to a relative } \\
\text { with similar complaints. }\end{array}$ & 51 & 14,9 & 262 & 76,6 & 29 & 8,5 \\
\hline $\begin{array}{l}\text { 3. The physician decides whether we need medication when } \\
\text { we get sick. }\end{array}$ & 323 & 94,4 & 13 & 3,8 & 6 & 1,8 \\
\hline $\begin{array}{l}\text { 4. Medications can have both positive and negative side } \\
\text { effects. }\end{array}$ & 320 & 93,6 & 13 & 3,8 & 9 & 2,6 \\
\hline 5. All medicines produce the same side effects. & 30 & 8,8 & 284 & 83,0 & 28 & 8,2 \\
\hline $\begin{array}{l}\text { 6. It is not harmful to take the medication more frequently } \\
\text { than the time intervals indicated by the physician. }\end{array}$ & 74 & 21,6 & 230 & 67,3 & 38 & 11,1 \\
\hline $\begin{array}{l}\text { 7. It can be learned from the instructions for use that } \\
\text { medicines should be taken on an empty or full stomach. }\end{array}$ & 307 & 89,8 & 19 & 5,6 & 16 & 4,7 \\
\hline $\begin{array}{l}\text { 8. Not using the medication for the duration of the treatment } \\
\text { prescribed by the doctor may hinder healing. }\end{array}$ & 259 & 75,7 & 61 & 17,8 & 22 & 6,4 \\
\hline 9. Herbal products can be used instead of medications. & 148 & 43,3 & 149 & 43,6 & 45 & 13,2 \\
\hline $\begin{array}{l}\text { 10. Consuming herbal products as much as desired does not } \\
\text { cause any harm to health. }\end{array}$ & 46 & 13,5 & 245 & 71,6 & 51 & 14,9 \\
\hline $\begin{array}{l}\text { 11. In the event of any undesirable effects while taking } \\
\text { medication, we should consult our physician immediately. }\end{array}$ & 335 & 98,0 & 6 & 1,8 & 1 & 0,3 \\
\hline $\begin{array}{l}\text { 12. While our physician arranges our treatment, we must } \\
\text { inform the drugs we are currently using. }\end{array}$ & 334 & 97,7 & 5 & 15 & 3 & 0,9 \\
\hline $\begin{array}{l}\text { 13. When we feel well during treatment, we can stop using } \\
\text { medication. }\end{array}$ & 107 & 31,3 & 195 & 57,0 & 40 & 11,7 \\
\hline $\begin{array}{l}\text { 14. We can ask our pharmacist where to keep our medications } \\
\text { at home. }\end{array}$ & 284 & 83,0 & 46 & 13,5 & 12 & 3,5 \\
\hline 15. The duration of treatment of each drug is the same. & 24 & 7,0 & 289 & 84,5 & 29 & 8,5 \\
\hline 16. Herbal products are completely harmless. & 28 & 8,2 & 256 & 74,9 & 58 & 17,0 \\
\hline $\begin{array}{l}\text { 17. Medicines can be used in the same dosage in all age } \\
\text { groups. }\end{array}$ & 25 & 7,3 & 305 & 89,2 & 12 & 3,5 \\
\hline $\begin{array}{l}\text { 18. Using a sufficient number of drugs ensures our recovery } \\
\text { rather than using a large number of drugs. }\end{array}$ & 297 & 86,8 & 28 & 8,2 & 17 & 5,0 \\
\hline 19. Expensive drugs are more effective. & 31 & 9,1 & 278 & 81,3 & 33 & 9,6 \\
\hline 20. Every drug can be used safely during pregnancy. & 18 & 5,3 & 312 & 91,2 & 12 & 3,5 \\
\hline 21. Some drugs have addictive properties. & 276 & 80,7 & 16 & 4,7 & 50 & 14,6 \\
\hline
\end{tabular}

The distribution of the participants' answers given to the questions in the health perception scale is shown in Table 3. 


\section{Table 3. The Distribution of the Participants' Answers Given to the Questions in the Health Perception Scale}

\begin{tabular}{|c|c|c|c|c|c|c|c|c|c|c|}
\hline \multirow[t]{2}{*}{ Statements $(\mathrm{N}=342)$} & \multicolumn{2}{|c|}{ Strongly Disagree } & \multicolumn{2}{|c|}{ Disagree } & \multicolumn{2}{|c|}{ Undecided } & \multicolumn{2}{|c|}{ Agree } & \multicolumn{2}{|c|}{ Strongly Agree } \\
\hline & $\mathbf{N}$ & $\%$ & $\mathbf{N}$ & $\%$ & $\mathbf{N}$ & $\%$ & $\mathbf{N}$ & $\%$ & $\mathbf{N}$ & $\%$ \\
\hline 1. I care about my health a lot & 8 & 2,3 & 21 & 6,1 & 28 & 8,2 & 166 & 48,5 & 119 & 34,8 \\
\hline 2. Being healthy is largely a matter of luck. & 60 & 17,5 & 144 & 42,1 & 35 & 10,2 & 66 & 19,3 & 37 & 10,8 \\
\hline $\begin{array}{l}\text { 3. Whatever I do, if I'm going to be healthy or sick, } \\
\text { whatever happens, will happen. }\end{array}$ & 72 & 21,1 & 162 & 47,4 & 26 & 7,6 & 50 & 14,6 & 32 & 9,4 \\
\hline 4. If I am healthy, I think this is a blessing from God. & 24 & 7,0 & 68 & 19,9 & 31 & 9,1 & 95 & 27,8 & 124 & 36,3 \\
\hline 5. I stay healthy if I exercise and eat right. & 6 & 1,8 & 16 & 4,7 & 23 & 6,7 & 163 & 47,7 & 134 & 39,2 \\
\hline $\begin{array}{l}\text { 6. I am often confused about what I should do to be } \\
\text { healthy }\end{array}$ & 44 & 12,9 & 141 & 41,2 & 64 & 18,7 & 65 & 19,0 & 28 & 8,2 \\
\hline $\begin{array}{l}\text { 7. I would like to be healthier, but I cannot do what I } \\
\text { have to do yet. }\end{array}$ & 22 & 6,4 & 85 & 24,9 & 35 & 10,2 & 138 & 40,4 & 62 & 18,1 \\
\hline $\begin{array}{l}\text { 8. There is so much different information on the types of } \\
\text { healthy foods that I don't know what to do. }\end{array}$ & 23 & 6,7 & 102 & 29,8 & 57 & 16,7 & 111 & 32,5 & 49 & 14,3 \\
\hline $\begin{array}{l}\text { 9. I am willing to spend more money on things that are } \\
\text { healthy for me. }\end{array}$ & 24 & 7,0 & 49 & 14,3 & 55 & 16,1 & 145 & 42,4 & 69 & 20,2 \\
\hline 10. Whether I'm healthy or not is up to me. & 12 & 3,5 & 62 & 18,1 & 53 & 15,5 & 127 & 37,1 & 88 & 25,7 \\
\hline $\begin{array}{l}\text { 11. My health is the most important consideration in my } \\
\text { life. }\end{array}$ & 4 & 1,2 & 35 & 10,2 & 42 & 12,3 & 126 & 36,8 & 135 & 39,5 \\
\hline 12. Being healthy is a matter of luck. & 77 & 22,5 & 141 & 41,2 & 43 & 12,6 & 55 & 16,1 & 26 & 7,6 \\
\hline 13. Whatever I do I can't improve my health & 89 & 26,0 & 165 & 48,2 & 29 & 8,5 & 29 & 8,5 & 30 & 8,8 \\
\hline 14. I can be as healthy as I desire & 23 & 6,7 & 117 & 34,2 & 67 & 19,6 & 92 & 26,9 & 43 & 12,6 \\
\hline $\begin{array}{l}\text { 15. I can't understand everything I've read about healthy } \\
\text { nutrition }\end{array}$ & 54 & 15,8 & 141 & 41,2 & 49 & 14,3 & 67 & 19,6 & 31 & 9,1 \\
\hline
\end{tabular}

The comparison of RDU and Perception of Health scores of the participants with socio-demographic variables is presented in Table 4. 
Table 4. The Comparison of RDU and Perception of Health Scores of the Participants with Socio-Demographic Variable

\begin{tabular}{|c|c|c|c|c|c|c|c|c|c|c|c|c|c|}
\hline & & \multirow{2}{*}{\multicolumn{6}{|c|}{ RDU Scale }} & & & & & & \\
\hline \multirow{3}{*}{\multicolumn{2}{|c|}{ Demographic variables ( $N=342$ ) }} & & & & & & & \multicolumn{6}{|c|}{ Health Perception Scale } \\
\hline & & \multirow[b]{2}{*}{$\mathrm{n}$} & \multirow{3}{*}{$\frac{\overline{\mathbf{X}} \pm \text { SS (MEAN) }}{27,00 \pm 9,34}$} & \multirow{3}{*}{$\frac{\text { M [IQR] (MEDIAN) }}{27,05[18.00]}$} & \multirow[b]{2}{*}{$x 2 / 2$} & \multirow{3}{*}{$\mathbf{P}$} & \multirow{2}{*}{$\begin{array}{c}\text { DIFFERENCE* } \\
* *\end{array}$} & \multirow[b]{2}{*}{$\mathbf{n}$} & \multirow{2}{*}{$\begin{array}{c}\bar{X} \pm S S \\
\text { (MEAN) }\end{array}$} & \multirow{2}{*}{$\begin{array}{c}\text { M [IQR] } \\
\text { (MEDIAN) }\end{array}$} & \multirow[b]{2}{*}{$x 2 / z$} & \multirow{3}{*}{$\mathbf{P}$} & \multirow{2}{*}{$\begin{array}{c}\text { DIFFERENCE* } \\
* *\end{array}$} \\
\hline & & & & & & & & & & & & & \\
\hline & a Literate & 4 & & & & & & 4 & $48,00 \pm 3,65$ & $48,00[7,00]$ & & & \\
\hline & ${ }^{\mathrm{b}}$ Primary School & 26 & $30,00 \pm 7,06$ & $31,00[10.25]$ & & & & 26 & $48,76 \pm 8,60$ & $49,50[16,25]$ & $20,91 *$ & 0,01 & d-e-f \\
\hline & ' High School & 61 & $34,29 \pm 5,06$ & $35,00[6.00]$ & $48,30 *$ & 0,00 & b-c-d-e-f & 61 & $49,98 \pm 7,31$ & $49,00[12,00]$ & & & \\
\hline Personal & ${ }^{\mathrm{d}}$ Undergraduate & 109 & $35,78 \pm 5,37$ & $36,00[6.00]$ & & & & 109 & $49,72 \pm 7,49$ & $49,00[9,00]$ & & & \\
\hline Educational & $\mathrm{e}$ Graduate & 42 & $37,07 \pm 3,65$ & $37,00[5.00]$ & & & & 42 & $53,85 \pm 7,23$ & $55,00[9,25]$ & & & \\
\hline \multirow[t]{3}{*}{ status } & ${ }^{f}$ Doctorate & 100 & $37.71 \pm 3.39$ & $38,00[14.00]$ & & & & 100 & $53,05 \pm 7,33$ & $52,50[9,00]$ & & & \\
\hline & a llliterate & a153 & $34,60 \pm 5,97$ & $36,00[7.50]$ & & & $a-b-d-e$ & 153 & $50,84 \pm 8,14$ & $51,00[11,50]$ & & & \\
\hline & ${ }^{\mathrm{b}}$ Literate & b64 & $36,78 \pm 3,60$ & $37,00[6.00]$ & $14,82 *$ & 0,05 & & 64 & $51,46 \pm 7,08$ & $50,00[8,75]$ & $0,73 *$ & 0,94 & \\
\hline Maternal & ' Primary School & $\mathrm{c} 84$ & $35,79 \pm 5,38$ & $38,00[5.00]$ & & & & 84 & $51,45 \pm 7,33$ & $52,00[10,00]$ & & & \\
\hline Educational & ${ }^{\mathrm{d}}$ High School & $d_{31}$ & $37,58 \pm 3,70$ & $36,00[6.00]$ & & & & 31 & $50,51 \pm 6,45$ & $50,00[13,00]$ & & & \\
\hline \multirow[t]{3}{*}{ Status } & e Graduate & e10 & $38,90 \pm 2,64$ & $39,00[8.00]$ & & & & 10 & $53,40 \pm 9,09$ & $51,00[18,00]$ & & & \\
\hline & a Illiterate & 50 & $33,36 \pm 5,97$ & $34,00[8.00]$ & & & & 50 & $48,82 \pm 8,04$ & $48,50[11,25]$ & $8,20 *$ & 0,85 & \\
\hline & ${ }^{\mathrm{b}}$ Literate & 64 & $35,29 \pm 5,15$ & $36,00[8.00]$ & & & & 64 & $52,54 \pm 9,14$ & $52,50[13,00]$ & & & \\
\hline Paternal & ${ }^{\mathrm{C}}$ Primary School & 117 & $35,98 \pm 5,19$ & $37,00[6.00]$ & $16,16 *$ & 0,03 & a-d-e & 117 & $51,84 \pm 6,97$ & $52,00[9,50]$ & & & \\
\hline Educational & ${ }^{\mathrm{d}}$ High School & 78 & $36,60 \pm 5,10$ & $38,00[6.00]$ & & & & 78 & $48,74 \pm 5,95$ & $51,00[9,25]$ & & & \\
\hline \multirow[t]{4}{*}{ Status } & ${ }^{\mathrm{e}}$ Graduate & 33 & $36,87 \pm 4,48$ & $38,00[6.00]$ & & & & 33 & $52,09 \pm 8,67$ & $50,00[14,50]$ & & & \\
\hline & aAcademic staff & 152 & $37,03 \pm 4,70$ & $38,00[4.00]$ & & & & 152 & $52,83 \pm 7,33$ & $53,00[10,00]$ & & & \\
\hline & ${ }^{\mathrm{b}} \mathrm{Administrative} \mathrm{staff}$ & 114 & $36,16 \pm 4,12$ & $36,50[6.00]$ & $41,15 *$ & 0,00 & $a-b-d$ & 114 & $50,62 \pm 7,24$ & $50,00[9,25]$ & $17,54 *$ & 0,01 & $a-d$ \\
\hline & d Security guard & 27 & $34,03 \pm 6,33$ & $36,00[6.00]$ & & & & 27 & $50,07 \pm 7,21$ & $50,0014,00]$ & & & \\
\hline \multirow[t]{5}{*}{ Profession } & e Cleaning services & 49 & $31,38 \pm 6,47$ & $33,00[9.50]$ & & & & 49 & $47,79 \pm 8,35$ & $47,00[12,00]$ & & & \\
\hline & a Very low & 17 & $30,11 \pm 6,53$ & $32,00[8.50]$ & & & & 17 & $44,41 \pm 7,52$ & $45,00[8,50]$ & & & \\
\hline & b Poor & 29 & $33,96 \pm 6,23$ & $35,00[6.00]$ & $24,63 *$ & 0,00 & $a-c-d-e$ & 29 & $50,13 \pm 9,36$ & $50,00[14,00]$ & 23,29 & 0,00 & a-c-d-e \\
\hline & Moderate & 172 & $35,56 \pm 5,48$ & $37,00[7.00]$ & & & & 172 & $50,54 \pm 7,29$ & $53,22[10,00]$ & & & \\
\hline & ${ }^{\mathrm{d}}$ Satisfactory & 110 & $37,04 \pm 3,84$ & $37,50[7.50]$ & & & & 110 & $52,91 \pm 6,72$ & $53,00[08,50]$ & & & \\
\hline \multirow[t]{3}{*}{ Financial Status } & ${ }^{\mathrm{e}} \mathrm{High}$ & 14 & $37,14 \pm 4,14$ & $40,00[5.25]$ & & & & 14 & $55,14 \pm 8,63$ & $56,50[11,25]$ & & & \\
\hline & a Nuclear & 259 & $36,28 \pm 4,88$ & $37,00[6.00]$ & $16,24 *$ & 0,00 & $a-b$ & 259 & $51,36 \pm 7,50$ & $51,00[11,00]$ & $4,74 *$ & $0,09 *$ & \\
\hline & ${ }^{b}$ Extended & 77 & $34,28 \pm 5,78$ & $36,00[6.50]$ & & & & 77 & $50,98 \pm 7,93$ & $52,00[11,00]$ & & & \\
\hline \multirow[t]{2}{*}{ Family type } & cBroken & 6 & $28,33 \pm 8,31$ & $31,50[16.25]$ & & & & 6 & $44,33 \pm 6,43$ & $45,50[11,50]$ & & & \\
\hline & Male & 271 & & $36,00[7.00]$ & $-4,10$ & $0,00 * *$ & & 271 & & $51[11,00]$ & $-0,89$ & $0,37 * *$ & \\
\hline Gender & Female & 71 & & $38,00[4.00]$ & & & & 71 & & $51[11,00]$ & & & \\
\hline \multirow[t]{2}{*}{ Marital status } & Single & 93 & & $36,00[5.00]$ & $-1,73$ & $0,08 * *$ & & 93 & & $50[11,50$ & $-0,17$ & $0,98 * *$ & \\
\hline & Married & 249 & & $37,00[6.00]$ & & & & 249 & & $51[10,50]$ & & & \\
\hline Distance from & Less than $1 \mathrm{~km}$ & 164 & & $38,00[6.00]$ & $-2,29$ & $0,02 * *$ & & 164 & & $51,50[11,00]$ & $-0,90$ & $0,36 * *$ & \\
\hline $\begin{array}{l}\text { Residence to } \\
\text { HealthFacilities }\end{array}$ & More than $1 \mathrm{~km}$ & 178 & & $36,00[7.25]$ & & & & 178 & & $50,50[10,00]$ & & & \\
\hline
\end{tabular}

*Spearman correlation analysis was performed.

*** The Mann-Whitney U test with Bonferroni correction was used as a post-hoc procedure to determine the source of the difference as a result of the Kruskal-Wallis Test. 
It was revealed that the Rational Drug Use of the participants in the study is affected by several factors such as personal and parental educational status, profession, socioeconomic level, family type, gender, and distance from the health facility to a residence. Factors affecting individuals' perception of health included personal educational status, profession, and socioeconomic level.

There was a statistically significant correlation between RDU and HP scales total mean scores of the participants included in the study, indicating a weak positive correlation $(\mathrm{r}=0,300 \mathrm{p}=0,000)$ (see Table $5)$.

Table 5. The correlations between RDU and HP scale total mean scores

\begin{tabular}{lcr}
\hline Scales* & RDU scale & HP scale \\
\hline RDU scale & 1 & $\mathrm{r}=0,300^{* *}$ \\
& $\mathrm{p}=0,000$ \\
HP scale & $\mathrm{r}=0,300^{* *}$ \\
$\mathrm{p}=0,000$ & 1 \\
\hline *Spearman correlation analysis was performed. \\
**The correlation is significant at 0,01 level.
\end{tabular}

Due to medical advances and greater access to healthcare facilities, the use of drugs is increasing rapidly. On the other hand, some studies show that the issues related to RDU have gradually evolved into an important public health problem. In line with that, it is stated that approximately $50,0 \%$ of the drugs taken today are used improperly. ${ }^{17}$ It is possible to encounter many challenges that concern individuals and institutions involved in the production, use, and disposal of drugs when necessary. These challenges are accompanied by various problems. These problems may be related to reasons involving both users and practitioners. User-induced errors spread over a wide spectrum including rational consumption of drugs, having drug information, multiple drug use, etc. ${ }^{7}$ In a study conducted by Yapic1 et al. (2011), it was found that $26,9 \%$ of the participants used drugs without taking the advice of a physician, $15,0 \%$ of them used the drugs available at home, and $43,7 \%$ of them quit taking the drugs before the required time. ${ }^{18}$ In a study by Özçelikay (2001), it was found that the rate of drug use without consulting a doctor was $75,5 \%$, and the most frequently used drugs included painkillers $(54,0 \%)$, antibiotics $(8,0 \%)$, and common cold medication $\quad(5,0 \%), \quad$ respectively. ${ }^{19}$ Practitioner-induced errors include those related to physician requests and protocols, medication administration errors, and errors due to the use of incorrect or inappropriate materials during service provision. RDU is one of the common health problems of both developing and developed countries. ${ }^{20}$

The RDU knowledge means score of the participants was found to be $35,69 \pm 5,30$. The participants who scored 35 or more on the scale were evaluated as having "Rational Drug Use knowledge". It was found that the participants had sufficient knowledge about RDU. However, there is no such study on academic staff in the literature. Demirci and Şimşek (2012) found that the participants' drug use attitudes were positive in their study on 238 people. ${ }^{21}$ Bayrak (2018), in his study on 372 patients, revealed that the drug use behaviors of the patients were at a rational level though not at the desired level. In the present study, it was found that chronic illness and continuous drug use affect the knowledge of rational drug use and behaviors of the patients. ${ }^{22}$ In the study conducted by Peköz (2018) on 202 people, it was shown that there was not enough knowledge about rational drug use and the physicians had the most responsibility for this case. It was also revealed that $60,9 \%$ of the physicians stated that the information they provided to patients about the drugs was partially sufficient and $68.8 \%$ of them partially prescribed the drugs requested by the patients. ${ }^{23}$

The Rational Drug Use of the participants in the study is affected by factors such as personal and parental educational status, profession, socioeconomic level, family type, gender, and distance from the health center to the residence.

In the present study, it was found that the Rational Drug Use of the participants is slightly affected by gender (Male; 36,00, Female 38,00 p=0,00). RDU scale means the 
score was found to be higher among women compared to men. In a study conducted with university students in 2020 on the subject, the RDU mean score of female students was found to be higher than male students. ${ }^{24}$ Similarly, in the study conducted by Demirtaş et al., women $(36,0 ; 11,0-42,0)$ were found to be more successful and conscious than men in terms of rational drug use $(34,0 ; 6,0-42,0) .{ }^{15}$ In this respect, our results are consistent with the literature, which can be explained by the fact that women are more sensitive to the subject.

It was shown that the educational status, professions, and socioeconomic levels of the participants in the study also affected Rational Drug Use $(p=0,000)$. In a study conducted by Ercan and Biçer in Sivas (2019), several differences were found between the educational status and professions of consumers and their Rational Drug Use behaviors. ${ }^{25}$ Our findings are consistent with the literature. Educational status and profession have a positive or negative impact on the behavior of individuals.

In this study, the distance from the health center to residence also influenced the Rational Drug Use of the participants $(\mathrm{p}<0,002)$. However, in a similar study conducted with the students of the Faculty of Health Sciences in Bandirma, it was found that the distance from the health center to residence did not affect the rational drug use of the students. ${ }^{26}$ In this respect, our findings do not overlap. However, the attitudes of individuals during illness are affected by many factors such as health perceptions, health knowledge levels, educational status, expectations from health institutions, distance from the health institution to the residence, etc. Therefore, this result obtained in the present study is an expected phenomenon.

The participants' perception of health total mean score was found to be $51,15 \pm 7,97$. Given the highest ( 75 points) and the lowest (15 points) scores on the scale, it can be suggested that the participants' perception of health mean scores are at a moderate level. In a study (2018) conducted on 19 May University Faculty of Health Sciences, nursing students' perception of health was found to be at a moderate level, too $(50,57 \pm 4,60) .{ }^{27}$ In another study conducted in 2016 with 356 employees working in two different factories affiliated to a private institution, their perception of health scale means the score was found to be $39,84 \pm 8,29$, indicating that their perception of health was moderate. ${ }^{28}$ In a study conducted in 2017 to determine the relationship between nursing students' perception of health and their selfconfidence, the HP score of the participants was found to be $49,61 \pm 6,28 .{ }^{29}$ Although the mean scores of perception of health in these four studies conducted in different segments of the society are similar to each other, the mean score of factory employees is lower than that of students in health sciences and university employees. In this sense, our findings draw a parallel with the literature. The perception of health is directly related to the health promotion process that aims to integrate healthy behaviors into one's life and to ensure the continuity of them. Besides, the perception of health affects the health behaviors and health responsibility of individuals.

The educational status $(\mathrm{p}<0,01)$, profession $(p<0,01)$, and socioeconomic levels $(p=0,00)$ of the participants who agreed to participate in our study are among the factors affecting the perception of health. In a study conducted in Kars in 2006 among the poor and non-poor women, no statistically significant difference was found between the perception of health and educational status in the poor group while a statistically significant difference was found between the perception of health and educational status in the non-poor group, indicating that the lower educational status is associated with decreased health perception. ${ }^{30}$ Vissandjee et al.'s study among Canadian women found that the perception of health was worse in those with a primary school education or below than those with a 
higher educational status. ${ }^{31}$ Ahmad et al. (2005) also found in their research that literacy level is associated with the perception of health and emphasized that educational status is an important factor in the perception of health. ${ }^{32}$ Belek (2004) monitored individuals for five years in his study on the subject and found that the higher educational status was associated with the higher perception of health. ${ }^{33}$ McMahon et al. (2003) concluded that that educational status is an important indicator of perception of health. ${ }^{34}$ Artazcoz et al. found that lower educational status poses a risk in terms of decreasing women's perception of health. ${ }^{35}$ Our findings are compatible with the literature and suggest that educational status is one of the many factors that affect the perception of health.

A profession is one of the factors that affect the perception of health. In a similar study conducted by Ohta et al., it was revealed that the perception of the health of workers, craftsmen, and transporters was more negative than other occupational groups. ${ }^{36}$ Our findings are similar to the results of other research.

The socioeconomic level is also one of the factors affecting the perception of health. Similar to our research results, the studies on the subject emphasize that individuals with a low socioeconomic level have a more negative perception of health. ${ }^{37,38}$

Considering the mean scores obtained from the sub-dimensions of the health perception scale, the highest mean score arises from the control center sub-dimension with $16,55 \pm 4,46$, followed by the certainty with $12,09 \pm 3,49$, the importance of health with $11,64 \pm 2,26$ and self-awareness subdimension with $10,85 \pm 2,37$, respectively. ${ }^{11}$ In a study conducted with 19 May University Faculty of Health Sciences, nursing department students (2016), the results were found in parallel with those of our research. According to the findings of this study, given the mean scores from the sub-dimensions of the Health Perception Scale, the highest mean score comes from the control center sub-dimension with $17,372,87$, followed by the certainty with $11,75 \pm 2,24$, importance of health with $10,73 \pm 1,95$ and self-awareness sub-dimension with $10,48 \pm 1,89$, respectively.

A statistically significant relationship was found between the RDU and HP total scores of the participants included in the study. A weak positive correlation $(\mathrm{r}=0,300 \mathrm{p}=0,000)$ was found between the RDS and HP scales of the participants. Based on these findings, it can be argued that the more health perceptions of the participant's increase, the more their knowledge of rational drug use also increases.

\section{CONCLUSION AND RECOMMENDATIONS}

To take important actions in rational drug use and health perception, first of all, the current situation of these issues should be revealed. Determining the knowledge levels and attitudes of individuals on these issues will be an important starting point for the steps to be taken in this respect.

It has been observed that individuals have sufficient knowledge of RDU, and factors such as Rational Drug Use of the individuals are affected by personal and parental educational status, profession, socioeconomic level, family type, gender, and the distance from the health center to the residence.
It has been determined that the participants' perception of health mean score is moderate, and factors such as education, profession, and socioeconomic level are effective in health perception. The relationship between the participants' RDU and HP total scores was found to be statistically significant. Also, a weak positive correlation as found between the RDU and HP scales of the participants. Training, researches, and social policies aimed at promoting the perception of health and drug use should be made widespread. In particular, not taking the medications prescribed by the physician without the 
physician's recommendation or as prescribed by the physician poses a problem in terms of rational drug use. It can be suggested that physicians inform patients about drugs while prescribing them, pharmacists provide more explanatory information to patients about drug use, and rational drug use is integrated into the formal education curriculum. The special reasons that lead society to use drugs without the recommendation of a physician should be thoroughly investigated. Administrative plans can be implemented more effectively to protect and develop the attitudes and behaviors gained through education. A set of consciousness related to not using drugs that are not prescribed for an individual should be established in society. Brochures, informative advertisements, training, and seminars on the subject in public education centers can be considered to preserve the current accurate level of knowledge and promote it to higher levels. In particular, society should be informed and trained about unnecessary drug use and disposed drugs and the effects of these on both economy and the environment. Although the primary responsibility in this respect falls on the administrator who is concerned with the situation, all individuals that make up our society have a duty in this regard. It is not possible to generalize the findings obtained with this study throughout Turkey. However, this study contributes to a better understanding of the big landscape to some extent in Turkey. It is thought that the data obtained from this study will contribute to the relevant literature.

\section{REFERENCES}

1. Kayaalp, S.O. (2012). "Akılcı Tedavi Yönünden Tıbbi Farmakoloji',. Ankara: Pelikan Yayıncılık.

2. Kosovalı, B.D. ve Yıldız, H. (2019). "Yoğun Bakım Ünitesi'nde Takip Edilen Dört Yıllık Akut İntoksikasyon Olgularının Retrospektif Değerlendirilmesi', Turkish Journal of Intensive Care, 17 (2), 75-81.

3. Türkiye İlaç ve Tıbbi Cihaz Kurumu. (2021). "Akılcı İlaç Kullanımı". Erişim adresi: http://www.akilciilac.gov.tr/?page_ id=81. (Erişim tarihi 23.01.2021).

4. WHO. (2021). "Promoting Rational Use of Medicines", Erişim adresi: https://www.who.int/activities/promotingrational-use-of-medicines. (Erişim tarihi: 05.05.2021).

5. Ulusoy, H.B, Sumak, T, Şahin, S. ve Gültekin, H. (2011) "Kayseri'de Pratisyen Hekimlere Verilen Groningen Modeli Akılcı İlaç Kullanımı Eğitiminin Değerlendirilmesi”. Erciyes Tip Dergisi, 33 (4), 309-316.

6. Akıc1, A, Uğurlu, M.Ü, Gönüllü, N, Oktay, Ş. ve Kalaça, S. (2002). Pratisyen "Hekimlerin Akılcı İlaç Kullanım Konusunda Bilgi ve Tutumlarının Değerlendirilmesi", STED, 11 (7), 253-257.

7. Ekenler, Ş. ve Koçoğlu, D. (2016). "Bireylerin Akılcı İlaç Kullanımıyla İlgili Bilgi ve Uygulamaları', Hacettepe Üniversitesi Hemşirelik Fakültesi Dergisi, 3 (3), 44-55.

8. Deniz, S. (2019). "Akılcı İlaç Kullanımına İlişkin Tutum ve Davranışların Belirlenmesine Yönelik Bir Araștırma", Hacettepe Sağlık İdaresi Dergisi, 22 (3), 619-632.

9. Ambwani, S. and Mathur, A.K. (2006). "Rational Drug Use', Health Administrator, 19 (1), 5-7.

10. Cengiz, Z. (2018). "Hemodiyaliz Hastalarına Sağlık İnanç Modeli Doğrultusunda Verilen Eğitimin Akılcı İlaç Kullanımı Üzerine Etkisi” (Doktora Tezi), İnönü Üniversitesi Sağlık Bilimleri Enstitüsü, Malatya.

11. Özdelikara, A, Alkan, S.A. ve Mumcu, N. (2018). "Hemşirelik Öğrencilerinde Sağlık Algısı, Sağlık Anksiyetesi ve Etkileyen Faktörlerin Belirlenmesi', Bakırköy Tıp Dergisi, 4 (3), 275-282.

12. Açıksöz, S, Uzun, Ş. ve Arslan, F. (2013). "Hemşirelik Öğrencilerinin Sağlık Algısı İle Sağlığı Geliștirme Davranışları Arasındaki İlişskinin İncelenmesi'”. Gülhane T1p Dergisi, 55 (3), e181-e187.

13. Whitehead, D. (2005). "Health-Promoting Hospitals: The Role and Function of Nursing', J Clin Nurs, 14 (1), 20-27.
14. Tuğut, N. ve Bekar, M. (2008). "Üniversite Öğrencilerinin Sağlığı Algılama Durumları İle Sağlıklı Yaşam Biçimi Davranışları Arasındaki İlișki',. Anadolu Hemșirelik ve Sağlık Bilimleri Dergisi, 11 (3), 17-26.

15. Demirtaş, Z, Dağtekin, G, Sağlan, R, Alaiye, M, Önsüz, M.F, Issıklı, B, Kılıc, F.S. ve Metintas, S. (2018). "Akılcı İlaç Kullanımı Ölçeği Geçerlilik ve Güvenilirliği", Eskişehir Türk Dünyası Uygulama ve Araştırma Merkezi Halk Sağlığı Dergisi, 3 (3), 37-46.

16. Kadığlu, H. ve Yıldız, A. (2012). "Sağlık Algısı Ölçeği'nin Türkçe Çevriminin Geçerlilik ve Güvenilirliği”. Türkiye Klinikleri Tip Bilimleri Dergisi, 2012, 32 (1), 47-53.

17. Ulupınar, S. ve Akıcı, A. (2015). "Hemşirelik Uygulamalarında Akılcı İlaç Kullanımı', Türkiye Klinikleri J Pharmacol-Special Topics, 3 (1), 84-93.

18. Yapıcı, G. Balıkçı, S. ve Uğur, Ö. (2011). "Birinci Basamak Sağlık Kuruluşuna Başvuranların İlaç Kullanımı Konusundaki Tutum ve Davranışları”. Dicle Tıp Dergisi, 38 (4), 458-465.

19. Özçelikay, G. (2001). “Akılıı İlaç Kullanımı Üzerinde Bir Pilot Çalıșma”. Ankara Eczacılık Fakültesi Dergisi, 30 (2), 9-18.

20. MacCannell, T, Perz, J.F, Srinivasan, A. and Schaefer, M.K (2010). "Bacterial and Parasitic Infections Associated with Extrinsically Contaminated Injectable Medications, United States 1999-2009.' In Fifth Decennial International Conference on Healthcare-Associated Infections, 1, 18-22.

21. Aksoy, A. (2012). "Üniversite Öğrencilerinin İlaç Kullanımına Yönelik Tutumları'’. Vocational Education, 7 (4), 43-51

22. Bayrak, N.Y. (2018). Dahiliye Kliniklerinde Yatan Hastaların Akılcı İlaç Kullanımı Konusunda Bilgi ve Davranışlarının Belirlenmesi (Yüksek Lisans Tezi), Atatürk Üniversitesi Sağlık Bilimleri Enstitüsü, Erzurum.

23. Peköz, Ö. (2018). Araştırma Görevlilerinin Akılcı İlaç Kullanımına Yönelik Tutum ve Davranıșları (Tıpta Uzmanlık Tezi), İzmir Katip Çelebi Üniversitesi Aile Hekimliği Anabilim Dalı, İzmir.

24. Kurt, O, Oğuzöncül, A, Deveci, S.E. ve Pirinçci, E. (2020). "Bir Sosyal Bilimler Meslek Yüksekokulu Öğrencilerinin Akılcı İlaç Kullanımı Konusunda Bilgi ve Davranıșlarının Değerlendirilmesi”. ESTÜDAM Halk Sağlığı Dergisi, 5 (1), $62-72$ 
25. Ercan, T. ve Bicer, D.F. (2019). "The Evaluation of the Factors Affecting the Knowledge Levels and Behaviors of Consumers for Rational Drug Use: Example of Sivas". Business \& Management Studies: An International Journal, 7 (2), 998-1021.

26. Özkan, S. ve Aca, Z. (2018). "Akılcı İlaç Kullanımında Sağlıklı Yaşam Becerilerinin Etkisi”’. SGD-Sosyal Güvenlik Dergisi, 10 (2), 273-288.

27. Özdelikara, A, Alkan, S.A. ve Mumcu, N. (2018) "Hemşirelik Öğrencilerinde Sağlık Algısı, Sağlık Anksiyetesi ve Etkileyen Faktörlerin Belirlenmesi". Bakırköy Tıp Dergisi, 14 (3), 275-282.

28. Kolaç, N, Balcı, A.S, Şişman, F.N, Ataçer, B.E. ve Dinçer, S. (2018). "Fabrika Çalışanlarında Sağlıklı Yaşam Biçimi Davranışı ve Sağlık Algısı”. Bakırköy Tıp Dergisi, 14, 267 274.

29. Çaka, S.Y, Topal, S, Suzan, Ö.K, Çınar, N. ve Altınkaynak, S. (2017). "Hemșirelik Öğrencilerin Sağlık Algısı İle Özgüvenleri Arasındaki İlișki',. Journal of Human Rhythm, 3 (4), 198-203.

30. Capık, C. (2006). Yoksul ve Yoksul Olmayan Kadınlarda Sağlık Algısını Etkileyen Etmenlerin İncelenmesi (Doktora Tezi), Dokuz Eylül Üniversitesi Sağlık Bilimleri Enstitüsü, İzmir.

31. Vissandjee, B, Desmeules, M, Cao, Z. and Abdool, S. (2004). "Integrating Socio-Economic Determinants of Canadian Women's Health', BMC Women's Health, 4 (1), $1-12$.

32. Ahmad, K, Jafar, T.H. and Chaturvedi, N. (2005). "SelfRated Health in Pakistan: Results of A National Health Survey', BMC Public Health, 5 (1), 1-7.

33. Belek, İ. (2004). "Sosyoekonomik Konumda ve Sağlıkta Sınıfsal Eșitsizlikler: Antalya'da Bes Yıllık Bir Araștırma", Ankara: Turkish Medical Association Publications.

34. McMahon, C. and Mckay, A. (2006). "Inequalities in Perceived Health 2003'”. Erişim adresi: http://www.public health.ie/index.asp?locID=106\&docID=451. (Erişim tarihi: 05.05.2021).

35. Artazcoz, L, Borrell, C, Benach, J, Cortès, I. and Rohlfs, I. (2004). "Women, Family Demands and Health: The Importance of Employment Status and Socio-Economic Position'. Social Science \& Medicine, 59 (2), 263-274.

36. Ohta, A. (1998). "Differences in Lifestyle and Perceived Health in Different Occupations in A Community'. Journal of Occupational Health, 40 (4), 325-333.

37. Goldberg, P, Guéguen, A, Schmaus, A, Nakache, J.P. and Goldberg, M. (2001). "Longitudinal Study of Associations Between Perceived Health Status and Self-Reported Diseases in the French Gazel Cohort". Journal of Epidemiology \& Community Health, 55 (4), 233-238.

38. Iancu, I, Horesh, N, Lepkifker, E. and Drory, Y. (2003). "An Epidemiological Study of Depressive Symptomatology among Israeli Adults: Prevalence of Depressive Symptoms and Demographic Risk Factors". Isr J Psychiatry Relat Sci, 40 (2), 82-89. 